\title{
Genetic diversity, mating systems, and interpopulation gene flow in neotropical Hemionitis palmata L. (Adiantaceae)
}

\author{
TOM A. RANKER \\ University Museum and Department of EPO Biology, Campus Box 350, University of Colorado, Boulder, CO 80309-0350, \\ U.S.A.
}

\begin{abstract}
Molecular data from isozyme analyses were used to characterize levels and patterns of genetic diversity in populations of the neotropical cheilanthoid fern Hemionitis palmata. All populations exhibited lower levels of genetic diversity than most other fern species previously studied. Variability in fixation indices and estimated intragametophytic selfing rates suggest that the predominant mating system varies from outcrossing to moderate levels of selfing among populations. Populations were significantly genetically differentiated from each other and estimated levels of interpopulation gene flow were generally low (i.e. $N m<1.0$ ). The wide geographical distribution of $H$. palmata may be accounted for by the ability of founding individuals to inbreed. Such an ability, along with founder effects, may explain the observed high levels of genetic differentiation among populations.
\end{abstract}

Keywords: gene flow, genetic diversity, Hemionitis, mating systems.

\section{Introduction}

Among studies of vascular plants, considerable experimental and theoretical work has been conducted on the population genetics of angiosperms and gymnosperms (see Hamrick \& Godt, 1990), but only recently have there been similar studies of pteridophytes (e.g. Haufler, 1987; Peck et al., 1990; Soltis \& Soltis, 1987a, 1990). Empirical studies of primarily north temperate, homosporous ferns have demonstrated that most species are either primarily outcrossing, with relatively high levels of genetic variability (Gastony \& Gottlieb, 1985; Haufler, 1985; Soltis \& Soltis, 1987a and references therein, 1990; Wolf et al., 1988), or primarily selfing, with consequent lower levels of variability (McCauley et al., 1985; Soltis \& Soltis, 1986). These results are similar to those from studies of angiosperms (see Barrett \& Eckert, 1990; Schemske \& Lande, $1985)$ and generally support the theoretical model of Lande \& Schemske (1985) which predicts a bimodal distribution of outcrossing rates among species as alternative, evolutionarily stable, reproductive modes. Evidence for mixed mating systems has been reported for only two species of homosporous ferns, Blechnum spicant (Soltis \& Soltis, 1988) and Dryopteris expansa (Soltis \& Soltis, 1987b), although it is not known if these represent equilibrium states.
In addition to their capacity for outcrossing and intergametophytic selfing (i.e. the union of gametes from separate gametophytes, both derived from the same parent, as with selfing in angiosperms and gymnosperms), homosporous ferns are capable of intragametophytic selfing, the result of the fusion of gametes derived from a single, bisexual gametophyte. Spores are the individual products of meiosis in homosporous ferns and germinate to produce free-living, multicellular gametophytes, each of which possesses the ability to become bisexual. Because both male and female gametes derived from such a gametophyte will be genetically identical at every locus (barring mutation) (e.g. Wilkie, 1963), the occurrence of intragametophytic self-fertilization will have a profound impact on the patterns and levels of genetic variability within and among conspecific populations. For example, high levels of intragametophytic selfing seem to account for the large inbreeding coefficients $\left(F_{\text {IS }}\right)$ estimated in species of Botrychium; $B$. dissectum has a mean $F_{\mathrm{IS}}$ of 0.951 (McCauley et al., 1985) and $B$. virginianum has a mean $F_{\text {IS }}$ of 0.957 (Soltis \& Soltis, 1986). The ability or inability to undergo intragametophytic selfing may also affect a variety of life-history attributes of a species (Crist \& Farrar, 1983; Peck et al. 1990 ), including colonization ability and ecological amplitude. The ability to self may also affect the genetic 
divergence of populations, modes of speciation, and the evolutionary potential of a phylogenetic lineage (e.g. Clegg, 1990). Although all homosporous fern gametophytes theoretically have the capacity for bisexuality and intragametophytic selfing, in many species effective or actual unisexuality and outcrossing are promoted by a variety of mechanisms (Klekowski, 1969; Näf, 1979; Peck et al., 1990; Schneller et al., 1990).

Recent studies of a variety of organisms have provided direct or indirect estimates of gene flow within and among natural populations (see Hamrick, 1987; Slatkin, 1987; and references therein). Several studies have demonstrated relationships between gene flow and various factors including dispersal ability (e.g. Waples, 1987), pollinator activity (e.g. Handel, 1983; Schaal, 1980), and mating systems (Hamrick, 1987 and references therein). Specific predictions can be made about the probability of genetic divergence of populations over time, given various levels of gene flow, when simplifying assumptions are made in theoretical models. These models typically assume random mating and no mutation or natural selection (Slatkin, 1985; Wright, 1931, 1943, 1951); however, Slatkin \& Barton (1989) recently demonstrated that even these assumptions can be relaxed. Wright (1931) demonstrated that, in the absence of natural selection, two populations are expected to diverge genetically as a result of genetic drift, if levels of gene flow are sufficiently low. Specifically, if a proportion $m$ of a population of effective size $N$ is replaced each generation by migrants from a source population, the two populations will diverge genetically if $N m<1.0$. Values of $N m$ greater than 1.0 will tend to maintain genetic homogeneity between populations at selectively neutral loci.

Studies of interpopulational gene flow have been conducted on only a few species of homosporous ferns. These studies have estimated relatively high levels of gene flow among populations of outcrossing species and lower levels among those of inbreeders (Soltis et al., 1988; Wolf et al., 1991). Of the two species with mixed mating systems, Blechum spicant showed relatively high levels of gene flow $(N m=2.95)$, whereas Dryopteris expansa exhibited much lower levels $(\mathrm{Nm}=0.83$; Soltis et al., 1988). Much more empirical evidence must be obtained on pteridophyte populations to test the generality of these early findings, incorporating data from a greater taxonomic, ecological, and geographical array of species.

The present study employed enzyme electrophoretic surveys of natural populations of the homosporous fern Hemionitis palmata L. (Adiantaceae) to assay levels of genetic diversity. Predominant mating systems operating within populations were inferred and levels of interpopulational gene flow were estimated.

Hemionitis palmata occurs from central Mexico to southern South America and variously in the West Indies; populations occur in a variety of mesic to seasonally dry habitats, ranging from rain forests and riparian communities to open, rocky hillsides.

\section{Materials and methods}

Whole plants were collected from sampled populations from Mexico, Jamaica, and Costa Rica and returned to the University of Kansas greenhouse for cultivation. Leaf material was collected from these living specimens for genetic analyses employing starch-gel electrophoresis. Electrophoretic conditions and locality information (see Table 1) are described in Ranker et al. (1989).

Several measures were calculated for each population to estimate overall levels of genetic diversity, including $P$, proportion of loci surveyed that were polymorphic, $A$, average number of alleles per locus (across all loci), and $H_{\mathrm{o}}$ and $H_{\mathrm{e}}$, average observed and expected heterozygosities (across all loci). Genetic differentiation of conspecific populations was estimated with Wright's standardized variance in allele frequencies, $F_{\text {ST }}$ (Nei, 1977; Wright, 1965, 1978) and Nei's unbiased genetic identity, $I$ (Nei, 1978), as calculated by Bıosys-1 (Release 1.7; Swofford \& Selander, 1989 ). Because $F_{\mathrm{ST}}$, as calculated by BIosYs-1, is a weighted average for all alleles at a locus, it is equivalent to $G_{\mathrm{ST}}$, the gene diversity among populations (Nei, 1973, 1977; Swofford \& Selander, 1989; Wright, 1978). The null hypothesis, $F_{\mathrm{ST}}=0$, was tested using the chi-square test of Workman \& Niswander $(1970)$ :

$\chi^{2}=2 N_{\mathrm{t}} F_{\mathrm{ST}}(k-1) ;$ d.f. $=(k-1)(s-1) ;$

where $N_{\mathrm{t}}$ is the total sample size at a locus, $k$ is the number of alleles, and $s$ is the number of populations.

Levels of inbreeding were estimated for each polymorphic locus, within populations, by the fixation index

$$
F=1-\left[H_{\mathrm{o}} / H_{\mathrm{e}}\right] \text {, }
$$

and summarized as weighted averages across populations by $F_{\text {IS }}$ (see Weir \& Cockerham, 1984). If $F$ is primarily determined by mating behaviour, it can be equated with an inbreeding coefficient (Wright, 1969). The significance of $F$ at each polymorphic locus in each population was calculated using a chi-square test of $H_{\mathrm{o}}$ versus $H_{\mathrm{e}}$. The null hypothesis, $F_{I \mathrm{~S}}=0$, was tested with the chi-square test of Li \& Horvitz (1953):

$\chi^{2}=F_{\mathrm{IS}}{ }^{2} N_{\mathrm{t}}(k-1) ;$ d.f. $=[k(k-1)] / 2$ 
Table 1 Allele frequencies at polymorphic loci

\begin{tabular}{|c|c|c|c|c|c|c|c|c|c|c|}
\hline \multirow[b]{2}{*}{ Locus } & \multirow[b]{2}{*}{ Allele } & \multicolumn{9}{|c|}{ Population* } \\
\hline & & $S A N G$ & $J 845$ & $J 849$ & $J 852$ & $J 853$ & $J 861$ & $J 862$ & $L S$ & $P A R G$ \\
\hline \multirow[t]{2}{*}{$P g i-2$} & 6 & 1.00 & 1.00 & 1.00 & 1.00 & 1.00 & 1.00 & 1.00 & 1.00 & \\
\hline & ${ }^{9}$ & 20 & 50 & 30 & 23 & 26 & 17 & 18 & 81 & 1.00 \\
\hline \multirow[t]{3}{*}{$H k$} & 8 & & 0.33 & 0.95 & 0.96 & 0.94 & 1.00 & 0.28 & 0.02 & 1.00 \\
\hline & 12 & 1.00 & 0.67 & 0.05 & 0.04 & 0.06 & & 0.72 & 0.98 & \\
\hline & $N$ & 18 & 24 & 21 & 23 & 26 & 17 & 18 & 81 & 49 \\
\hline \multirow[t]{3}{*}{$I d h$} & 13 & 0.86 & 1.00 & 0.23 & 0.20 & 0.40 & 1.00 & 1.00 & 1.00 & 1.00 \\
\hline & 17 & 0.14 & & 0.77 & 0.80 & 0.60 & & & & \\
\hline & $N$ & 29 & 50 & 39 & 23 & 26 & 17 & 18 & 81 & 49 \\
\hline \multirow[t]{4}{*}{ Lap } & 4 & 0.96 & 0.98 & 0.58 & 0.50 & 0.23 & 0.97 & 1.00 & & \\
\hline & 11 & 0.04 & 0.02 & 0.42 & 0.50 & 0.77 & 0.03 & & 1.00 & 0.14 \\
\hline & 15 & & & & & & & & & 0.86 \\
\hline & $N$ & 27 & 50 & 20 & 23 & 26 & 17 & 18 & 5 & 7 \\
\hline
\end{tabular}

*Localities of populations: $S A N G$ - Oaxaca, Mexico; J845 thru J862 - Jamaica; PARG \& LS - Costa Rica (see Ranker et al., 1989).

$N=$ sample size/population/locus.

with $N_{1}$ and $k$ defined as above. Estimates of intragametophytic selfing rates were obtained with the maximum likelihood, bootstrap- $t$ algorithm and computer program of Holsinger (1987), using $t=100$ resamplings for each population.

Values of $\mathrm{Nm}$ were calculated as estimates of interpopulational gene flow by the relationship:

$F_{\mathrm{ST}} \approx 1 /[4 N m+1]$

(Dobzhansky \& Wright, 1941; Wright, 1931, 1943, 1951), which assumes an island model of population structure. Slatkin \& Barton (1989) recently demonstrated, however, that the relationship provides reasonable estimates of $\mathrm{Nm}$ under a wide variety of population structures, in addition to the island model. They also demonstrated that by using $G_{\mathrm{ST}}$ as an approximation of $F_{\mathrm{ST}}$, as was done in the present study, reliable estimates of $\mathrm{Nm}$ could be obtained (Slatkin \& Barton, 1989), similar to those derived from the private-allele method of Slatkin (1985). In addition, they suggested that employing the $F_{\mathrm{ST}}$ method might actually be preferred over the private-allele method for electrophoretic data, given the intrinsic limitations of these data and potential problems due to sampling and gel-scoring errors involving the detection of rare, private alleles.

\section{Results}

Electrophoretic results were obtained from nine enzyme systems and for 10 putative loci: aspartate aminotransferase $(A a t)$, aldolase $($ Ald -2$)$, hexokinase
$(H k)$, isocitrate dehydrogenase $(I d h)$, leucine aminopeptidase (Lap), phosphoglucomutase (Pgm-2), phosphoglucose isomerase (Pgi-2), shikimate dehydrogenase $(S k d h)$ and triosephosphate isomerase (Tpi-1 and $T p i-2)$. Allele frequencies are listed for all populations at the four polymorphic loci, Pgi-2, Idh, $H k$ and Lap (Table 1). All other loci were monomorphic within and among populations.

\section{Population genetic diversity}

Relative to other fern species, populations of $H$. palmata exhibited low levels of genetic diversity (Table 2), similar to the inbreeder Botrychium virginianum (Soltis \& Soltis, 1986).

\section{Genetic differentiation of populations}

The sampled populations were generally highly divergent, with highly significant $F_{\mathrm{ST}}$ values at all four polymorphic loci (Table 3 ). Of the 36 possible comparisons between pairs of $H$. palmata populations, all but two produced highly significant $F_{\mathrm{ST}}$ values (Table 4 ). Jamaican populations $J 845$ and $J 862$ were genetically identical, as was the pair $J 849$ and $J 852$, with $F_{\text {ST }}$ values of 0.000 .

Pair-wise comparisons of populations produced genetic identities ranging from 0.71 to 1.00 , with a mean of 0.87 (Tables 4 and 5). The population from southern Costa Rica (PARG) was much more divergent from all other populations than were any of the 
Table 2 Population-level genetic diversity statistics. $P=$ Proportion of loci examined that were polymorphic at the $1 \%$ level; $A=$ number of alleles per locus (averaged across all loci); $H_{0}=$ average observed heterozygosity (across all loci); $H_{\mathrm{e}}=$ average expected heterozygosity under Hardy-Weinberg equilibrium (across all loci); $n=$ sample size; means are given because data were not obtained from all individuals for all loci. Standard error in parentheses

\begin{tabular}{|c|c|c|c|c|c|}
\hline Population* & $\begin{array}{l}\text { Mean } n \\
\text { per locus }\end{array}$ & $P$ & $A$ & $H_{\mathrm{o}}$ & $H_{\mathrm{e}}$ \\
\hline SANG & $25.4(2.0)$ & 0.20 & $1.20(0.13)$ & $0.020(0.020)$ & $0.032(0.025)$ \\
\hline$J 845$ & $47.4(2.6)$ & 0.20 & $1.20(0.13)$ & $0.062(0.058)$ & $0.049(0.045)$ \\
\hline$J 849$ & $33.2(3.0)$ & 0.30 & $1.30(0.15)$ & $0.056(0.039)$ & $0.095(0.058)$ \\
\hline$J 852$ & $20.8(2.2)$ & 0.30 & $1.30(0.15)$ & $0.070(0.042)$ & $0.092(0.057)$ \\
\hline$J 853$ & $26.0(0)$ & 0.30 & $1.30(0.15)$ & $0.077(0.043)$ & $0.096(0.057)$ \\
\hline$J 861$ & $17.0(0)$ & 0.10 & $1.10(0.10)$ & $0.006(0.006)$ & $0.006(0.006)$ \\
\hline$J 862$ & $18.0(0)$ & 0.10 & $1.10(0.10)$ & $0.022(0.022)$ & $0.041(0.041)$ \\
\hline$P A R G$ & $40.6(5.6)$ & 0.10 & $1.10(0.10)$ & $0.000(0.000)$ & $0.026(0.026)$ \\
\hline$L S$ & $65.8(10.1)$ & 0.10 & $1.10(0.10)$ & $0.000(0.000)$ & $0.005(0.005)$ \\
\hline & 0.19 & 1.19 & 0.035 & 0.049 \\
\hline & \multicolumn{5}{|c|}{ Population-level means for 11 species of outcrossing ferns $\dagger$} \\
\hline & & 0.36 & 1.67 & $-\S$ & 0.113 \\
\hline \multicolumn{6}{|c|}{ Population-level for inbreeding Botrychium virginianum $\ddagger$} \\
\hline & & 0.22 & 1.25 & $-\S$ & 0.035 \\
\hline
\end{tabular}

Abbreviations as in Table 1.

$\dagger$ Averaged from values reported in Gastony \& Gottlieb (1985), Haufler (1985),

Soltis \& Soltis (1987c), Soltis et al. (1990), and Wolf et al. (1988).

†From Soltis \& Soltis (1986).

$\S$ Not available for all species.

Table $3 \quad F_{\text {ST }}$ and $\mathrm{Nm}$ at polymorphic loci

\begin{tabular}{lll}
\hline Locus & $F_{\mathrm{ST}}$ & $N_{\mathrm{m}}$ \\
\hline Pgi-2 & $0.998^{* * *}$ & 0.001 \\
Hk & $0.723^{* * *}$ & 0.096 \\
Idh & $0.593^{* * *}$ & 0.172 \\
Lap & $0.642^{* * *}$ & 0.139 \\
Mean & $0.698^{* * *}$ & 0.102 \\
\hline
\end{tabular}

*** $P<0.001$.

other populations from each other (Tables 4 and 5). This was true even when $P A R G$ was compared to $L S$, the northern Costa Rican population. $P A R G$ was as equally divergent from $L S(I=0.73)$ as it was from the Mexican population $S A N G(I=0.71)$, and slightly more divergent from $L S$ than it was from the Jamaican populations (mean $I=0.78$ ). Concordantly, $L S$ was similar to populations from Mexico $(I=0.90)$ and Jamaica (mean $I=0.85$ ) more so than it was to PARG. The low genetic identities between $P A R G$ and other populations were primarily due to the fixation of a unique allele in this population at Pgi-2 and the high frequency $(0.86)$ of another unique allele at Lap.

\section{Estimates of inbreeding}

Values of $F$ and their degrees of statistical significance varied among loci and populations (Table 6). None of the fixation indices calculated for populations $J 845$, $J 853, J 861$, and $J 862$, were statistically different from zero.

\section{Intragametophytic selfing}

Estimated rates of intragametophytic selfing varied among populations (Table 7), ranging from 0.0000 to 0.5242 . Only two of the selfing estimates, $J 849$ $(0.4181)$ and $J 853(0.1760)$, had 95 per cent confidence intervals that did not include zero; hence, it is only in those two populations that significant levels of selfing can be hypothesized to have occurred. However, because the lower boundary of the selfing-rate confidence interval for population $J 853$ was very near zero (i.e. 0.0026), and none of the per locus fixation indices for that population were significantly different from zero (Table 6), selfing may not have occurred to a significant degree in that population. Due to the total absence of heterozygotes in populations from Costa Rica $(P A R G$ and $L S)$, it was not possible to calculate selfing rates with the algorithm employed. 
Table 4 Genetic differentiation of $H$. palmata populations and estimates of gene flow. Above diagonal: pairwise $F_{\mathrm{ST}}$ values (top) and Nei's genetic identities (bottom). Below diagonal: estimates of $\mathrm{Nm}$ 'nd' indicates cases where populations were not differentiated (i.e $\left.F_{\mathrm{ST}}=0 ; I=1.00\right)$, thus calculations of $\mathrm{Nm}$ were not possible using $F_{\mathrm{ST}}$

\begin{tabular}{|c|c|c|c|c|c|c|c|c|c|}
\hline & $S A N G$ & $J 845$ & $J 849$ & $J 852$ & $J 853$ & $J 861$ & $J 862$ & $L S$ & $P A R G$ \\
\hline \multirow[t]{2}{*}{$S A N G$} & - & $0.133^{* * *}$ & $0.528^{* * *}$ & $0.554^{* * *}$ & $0.555^{* * *}$ & $0.722^{* * *}$ & $0.109^{* * *}$ & $0.720^{* * *}$ & $0.829^{* * *}$ \\
\hline & & 0.99 & 0.85 & 0.83 & 0.83 & 0.90 & 0.99 & 0.91 & 0.71 \\
\hline \multirow[t]{2}{*}{$J 845$} & 1.63 & - & $0.438^{* * *}$ & $0.470^{* * *}$ & $0.467^{* * *}$ & $0.442^{* * *}$ & 0.000 & $0.659^{* * *}$ & $0.752^{* * *}$ \\
\hline & & & 0.88 & 0.87 & 0.86 & 0.96 & 1.00 & 0.89 & 0.76 \\
\hline \multirow[t]{2}{*}{$J 849$} & 0.22 & 0.32 & - & 0.000 & $0.064^{* *}$ & $0.420^{* * *}$ & $0.468^{* * *}$ & $0.639^{* * *}$ & $0.641^{* * *}$ \\
\hline & & & & 1.00 & 0.99 & 0.92 & 0.87 & 0.81 & 0.77 \\
\hline \multirow{2}{*}{$J 852$} & 0.20 & 0.28 & nd & - & $0.049^{* *}$ & $0.465^{* * *}$ & $0.499^{* * *}$ & $0.645^{* * *}$ & $0.651^{* * *}$ \\
\hline & & & & & 0.99 & 0.91 & 0.86 & 0.82 & 0.77 \\
\hline \multirow[t]{2}{*}{$J 853$} & 0.20 & 0.29 & 3.66 & 4.85 & - & $0.463^{* * *}$ & $0.497^{* * *}$ & $0.551^{* * *}$ & $0.613^{* * *}$ \\
\hline & & & & & & 0.91 & 0.85 & 0.87 & 0.80 \\
\hline \multirow[t]{2}{*}{$J 861$} & 0.10 & 0.32 & 0.35 & 0.29 & 0.29 & - & $0.519^{* * *}$ & $0.939^{* * *}$ & $0.848^{* * *}$ \\
\hline & & & & & & & 0.95 & 0.81 & 0.81 \\
\hline \multirow[t]{2}{*}{$J 862$} & 2.04 & nd & 0.28 & 0.25 & 0.25 & 0.23 & - & $0.695^{* * *}$ & $0.779^{* * *}$ \\
\hline & & & & & & & & 0.89 & 0.75 \\
\hline$L S$ & 0.10 & 0.13 & 0.14 & 0.14 & 0.20 & 0.02 & 0.11 & - & $\begin{array}{l}0.896^{* * *} \\
0.73\end{array}$ \\
\hline$P A R G$ & 0.05 & 0.08 & 0.14 & 0.13 & 0.16 & 0.04 & 0.07 & 0.03 & - \\
\hline
\end{tabular}

${ }^{* *} P<0.01 ;{ }^{* * *} P<0.001$.

\section{Interpopulation gene flow}

All per-locus estimates of $\mathrm{Nm}$ across all populations were well below 1.00 with a mean of 0.102 (Table 3). The generally low values across all polymorphic loci were consistent with the significant heterogeneities observed at those loci. Estimates of $\mathrm{Nm}$ between pairs of populations, however, revealed some variability (Table 4). The Mexican population, $S A N G$, was nearly genetically identical to the Jamaican populations $J 845$ and $J 862$ (pairwise $I=0.99$ in both cases), and estimates of $\mathrm{Nm}$ were both above 1.00 (1.63 and 2.04, respectively). Similarly, gene flow between the latter two populations was effectively infinite due to complete genetic identity (i.e. $I=1.00$ ) at the loci examined. Pairwise estimates of $\mathrm{Nm}$ among $\mathrm{J} 849, \mathrm{~J} 852$ and $J 853$ were all greater than 1.00 or, as above, effectively infinite due to complete genetic identity between $J 849$ and $J 852$. (Note that when $F_{\mathrm{ST}}=0.0$, an exact value for $\mathrm{Nm}$ cannot be estimated because of 0.0 in the denominator of the expression relating $F_{\mathrm{ST}}$ to $\mathrm{Nm}$.)

\section{Discussion}

\section{Population genetic diversity and mating systems}

Variance in both intragametophytic selfing estimates (Table 7) and fixation indices (Table 6) among populations of $H$. palmata suggest that this tropical species has a mixed mating system similar to those reported for the north temperate taxa, Blechnum spicant (Soltis \& Soltis, 1988) and Dryopteris expansa (Soltis \& Soltis, $1987 \mathrm{~b})$. Although $H$. palmata is often found in seemingly stable, climax communities (Stoltze, 1981), it also invades disturbed sites such as river banks, road cuts, and banana or coffee plantations (T. A. Ranker personal observations; Tryon \& Tryon, 1982). The apparent variability in mating system of this species may both reflect and allow its wide ecological amplitude and its great geographical range from central Mexico and the Caribbean to southern South America.

Variability in mating system among populations could be influenced by a variety of mechanisms affecting sexual expression in gametophytic populations. These include, but are not limited to, sexual ontogeny (Klekowski, 1969; Lloyd, 1974) and the action of male-inducing pheromones called antheridiogens (Haufler \& Ranker, 1985; Näf, 1979; Schneller et al., 1990; Scott \& Hickok; 1987). Antheridiogens are produced by maturing gametophytes of some species and released into the surrounding substrate. Newly germinating gametophytes exposed to an antheridiogen-enriched substrate will become male only, whereas the more mature gametophytes become female, thus promoting intergametophytic crossing. Scott \& Hickok (1987) discovered variability in antheridiogen sensitivity in different natural strains of Ceratopteris richardii, as did Kirkpatrick (1988) among individuals within populations of Gymnocarpium dryopteris subsp. disjunctum, which suggests that such variability may 
Table 5 Genetic identities between conspecific populations. Mean pairwise values are given for $H$. palmata populations for comparisons involving more than two populations (ranges in parentheses)

\begin{tabular}{lll}
\hline Populations compared & $I$ & Source \\
\hline All populations & $0.87(0.71,1.00)$ & \\
All but $P$ ARG & $0.90(0.81,1.00)$ & \\
Jamaican populations & $0.92(0.85,1.00)$ & \\
Costa Rican populations & 0.73 & \\
Mexico vs. Jamaica & $0.90(0.83,0.99)$ & \\
Jamaica vs. & & \\
$\quad$ LS, Costa Rica & $0.85(0.81,0.89)$ & \\
PARG, Costa Rica & $0.78(0.75,0.81)$ & \\
Mexico vs. & & \\
$\quad$ LS, Costa Rica & 0.90 & \\
PARG, Costa Rica & 0.71 & \\
Blechnum spicant & 0.996 & P. Soltis \& D. Soltis $(1988)$ \\
Bommeria elegans & 0.790 & Ranker $(1987)$ \\
Bommeria hispida & 0.879 & Haufler $(1985)$ \\
Cheilanthes subcordata & 0.900 & Ranker $(1987)$ \\
Cystopteris bulbifera & 0.826 & Haufler et al. $(1990)$ \\
Cystopteris protrusa & 0.834 & Haufler et al. $(1990)$ \\
Pellaea andromedifolia & 0.943 & Gastony \& Gottlieb (1985) \\
Polystichum munitum & 0.997 & Soltis et al. $(1990)$ \\
P. acrostichoides & 0.998 & Soltis et al. $(1990)$ \\
P. dudleyi & 0.969 & Soltis et al. $(1990)$ \\
$P$. imbricans & 0.974 & Soltis et al. $(1990)$ \\
P. lemmonii & 0.989 & Soltis et al. $(1990)$ \\
P. lonchitis & 0.966 & Soltis et al. $(1990)$ \\
Pteridium aquilinum & & Wolf et al. $(1991)$ \\
British populations & 0.995 & \\
Majorca vs. Britain & 0.989 & \\
N. America vs. Europe & 0.681 & \\
\hline & & \\
\hline
\end{tabular}

Table 6 Fixation indices $(F)$ at individual polymorphic loci and values across populations within species $\left(F_{\text {IS }}\right)$. Blanks indicate monomorphic loci

\begin{tabular}{lllllllllll}
\hline Locus & SANG & J845 & $J 849$ & J852 & $J 853$ & $J 861$ & $J 862$ & $L S$ & PARG & $F_{\text {IS }}$ \\
\hline$H k$ & - & -0.312 & $1.000^{* * *}$ & -0.045 & -0.061 & - & 0.446 & $1.000^{* * *}$ & - & $0.143^{*}$ \\
Idh & 0.169 & - & $0.422^{*}$ & -0.243 & 0.281 & - & - & - & - & $0.179^{* * *}$ \\
Lap & $1.000^{*}$ & -0.020 & 0.284 & $0.565^{* *}$ & 0.133 & 0.016 & - & - & $1.000^{* *}$ & $0.445^{* * *}$ \\
\hline
\end{tabular}

${ }^{*} P<0.05 ;{ }^{* * *} P<0.001$.

not be uncommon in fern species. Schneller et al. (1990) have also presented preliminary evidence which demonstrates that individuals and populations of $H$. palmata differ in their sensitivity to antheridiogen.

Geographically widespread plant species typically show the highest levels of genetic variability (Hamrick \& Godt, 1990; Karron, 1987). The extremely low levels of genetic variability observed within populations of the widespread species $H$. palmata, however, are similar to those of the highly inbred species of Botrychium (McCauley, et al., 1985; Soltis \& Soltis, 1986; Table 2). Features of the mating system of $H$. palmata may increase its ability to colonize new habitats, and, therefore, be important in determining genetic diversity within and among populations. Recurring colonization events, spatially and temporally, would produce frequent genetic bottlenecks and could account for the extremely low levels of genetic 
Table 7 Estimates of intragametophytic selfing

\begin{tabular}{llll}
\hline Population & Selfing rate & $95 \%$ confidence interval & Loci employed \\
\hline SANG* & 0.1526 & $(0.0000,0.3663)$ & Idh \\
$J 845$ & 0.0000 & $(0.0000,0.0649)$ & Hk, Lap \\
$J 849$ & 0.4181 & $(0.1035,0.6890)$ & Hk, Idh, Lap \\
$J 852^{*}$ & 0.0000 & $(0.0000,0.0555)$ & Hk, Idh \\
$J 853$ & 0.1760 & $(0.0026,0.2992)$ & Hk, Idh, Lap \\
$J 861$ & 0.0000 & $(0.0000,0.0101)$ & Lap \\
$J 862$ & 0.5242 & $(0.0000,0.6666)$ & Hk \\
\hline
\end{tabular}

*Values represent estimates calculated after removing information from Lap which had statistically significant fixation indices in the two populations noted; inclusion of Lap caused significant departures from parameter estimates based on $G$ goodnessof-fit tests (see Holsinger, 1987; Soltis et al., 1988).

variation in both inbreeding and outcrossing populations of this species.

\section{Colonization history and gene flow among Jamaican populations}

A detailed analysis of the distribution of allele frequencies among Jamaican populations (Table 1) revealed spatial patterns that may reflect the colonization history of this species both onto Jamaica and among sites within Jamaica. The populations fall into two distinct groups of three each, based on allele frequencies at Lap and Idh, which suggests that the members of each trio share a more recent common ancestor than do the two trios (Table 1). The three populations from St Andrew Parish (J849, J852, and J853) all had high frequencies of $I d h^{17}$ and $L a p^{11}$ (superscripts refer to allelic designations), whereas the remaining three populations from Portland Parish to the north and Clarendon Parish to the west were fixed, or nearly so, for $I d h^{13}$ and $L a p^{4}$. The high genetic identities between the Mexican population of $H$. palmata $(S A N G)$ and two Jamaican populations from the latter trio ( $J 845$ and $J 862 ; I=0.99$ for both; Table 4) may indicate a relatively recent, long-distance dispersal event from one area to the other. The distributions of allele frequencies at $I d h$ and Lap imply that the ancestral populations of each trio resulted from separate colonization events. This could have occurred via two distinct colonizations from mainland sources or, alternatively, via one colonization onto Jamaica giving rise to a single founding population with subsequent dispersal producing a second genetically distinct population as a result of a sampling or founder effect. Under the latter scenario, additional populations would have been established from each distinct population via either recent spore dispersal and colonization or by more ancient dispersal followed by continued migration between populations. Either situation would prevent genetic divergence of populations within trios, as observed at $I d h$ and Lap.

Evidence from a third polymorphic locus $(H k$; Table 1) supports a close genetic relationship among the three populations from St Andrew Parish, with high frequencies of $H k^{8}$, and between two (J845 and J862) of the other three populations, with high frequencies of $H k^{12}$. The third population from the latter trio $(J 861)$ was fixed for $H k^{8}$, which could be accounted for by dispersal from $J 845$ or $J 862$ (or a different, but genetically similar, population) with a loss of $H k^{12}$ via a founder effect. Founder effects may also explain the observed genetic differentiation of the two populations sampled from Costa Rica (Tables 1 and 5).

In conclusion, the data support the hypothesis that mating behaviour and founder effects appear to be the primary factors controlling levels and patterns of genetic diversity within and among populations, as well as the colonization and migration ability of $H$. palmata.

\section{Acknowledgements}

I would like to thank Jim Schwartz, Pam Soltis, Genie Trapp, and Paul Wolf for providing helpful comments on an early draft of the manuscript. This work was supported in part by NSF Dissertation Improvement Grant BSR-8514431 and a Pierre Stouse, Jr. Memorial Scholarship awarded by the University of Kansas Endowment Association.

\section{References}

BARRETT, S. C. H. AND ECKERT, C. G. 1990. Variation and evolution. In: Kawano, S. (ed), Biological Approaches and Evolutionary Trends in Plants, Academic Press, New York. CLEGG, M. T. 1990. Molecular diversity in plant populations. In: Brown, A. H. D., Clegg, M. T., Kahler, A. L. and Weir, 
B. S. (eds), Plant Population Genetics, Breeding, and Genetic Resources, Sinauer Associates, Inc., Sunderland, MA.

CRIST, K. C. AND FARRAR, D. R. 1983. Genetic load and longdistance dispersal in Asplenium platyneuron. Can. J. Bot., 61, 1809-1814.

DOBZHANSKY, T. AND WRIGHT, s. 1941. Genetics of natural populations. V. Relations between mutation rate and accumulation of lethals in populations of Drosophila pseudoobscura. Genetics, 26, 23-51.

GASTONY, G. J. AND GOTTLIEB, L, D. 1985. Genetic variation in the homosporous fern Pellaea andromedifolia. Am. J. Bot., 72, 257-267.

HAMRICK, J. L. 1987. Gene flow and distribution of genetic variation in plant populations. In: Urbanska, K. M. (ed.), Differentiation Patterns in Higher Plants, Academic Press, Orlando, FL.

HAMRICK, J, L. AND GODT, M. J. W. 1990. Allozyme diversity in plant species. In: Brown, A. H. D., Clegg, M. T., Kahler, A. L. and Weir, B. S. (eds), Plant Population Genetics, Breeding, and Genetic Resources, Sinauer Associates, Inc., Sunderland, MA.

HANDEL, S. N. 1983. Contrasting gene flow patterns and genetic subdivision in adjacent populations of Cucumis sativus (Cucurbitaceae). Evolution, 37, 760-771.

HAUFLER, C. H. 1985. Enzyme variability and modes of evolution in Bommeria (Pteridaceae). Syst. Bot., 10, 92-104.

HAUFLER, C. H. 1987. Electrophoresis is modifying our concepts of evolution in homosporous pteridophytes. $\mathrm{Am}$. J. Bot., 74, 953-966.

HAUFLER, C. H. AND RANKER, T. A. 1985. Differential antheridiogen response and evolutionary mechanisms in Cystopteris. Am. J. Bot., 72, 659-665.

HAUFLER, C. H., WINDHAM, M. D. AND RANKER, T. A. 1990. Biosystematic analysis of the Cystopteris tennesseensis (Dryopteridaceae) complex. Ann. Missouri Bot. Gard., 77, 314-329.

HOLSINGER, K. E. 1987. Gametophytic self-fertilization in homosporous plants: development, evaluation, and application of a statistical method for evaluating its importance. Am. J. Bot., 74, 1173-1183.

KARRON, J. D. 1987. A comparison of levels of genetic polymorphism and self-compatibility in geographically restricted and widespread plant congeners. Evol. Ecol., 1, 47-58.

KIRKPATRICK, R. E. B. 1988. An analysis of the mating system of Gymnocarpium dryopteris ssp. disjunctum. Master's thesis. Washington State University, Pullman.

KLEKowSKI, E. J. JR. 1969. Reproductive biology of the Pteridophyta. II. Theoretical considerations. Bot. J. Linn. Soc., 62, 347-359.

LANDE, R. AND SCHEMSKE, D. W. 1985. The evolution of selffertilization and inbreeding depression in plants. I. Genetic models. Evolution, 39, 24-40.

LI, C. C. AND HORVITZ, D. G. 1953. Some methods of estimating the inbreeding coefficient. Am. J. Hum. Genet., 5., 107-117.

LLOYD, R. M. 1974. Mating systems and genetic load in pioneer and non-pioneer Hawaiian Pteridophyta. Bot. J. Linn.
Soc., 69, 23-35.

McCAULEY, D. E., WHITTIER, D. P. AND REILLY, L. M. 1985. Inbreeding and the rate of self-fertilization in a grape fern, Botrychium dissectum. Am. J. Bot., 72, 1978-1981.

NAF, U. 1979. Antheridiogens and antheridial development. In: Dyer, A. F. (ed.), The Experimental Biology of Ferns, Academic Press, London.

NEI, M. 1973. Analysis of gene diversity in subdivided populations. Proc. Natl. Acad. Sci. U.S.A., 70, 3321-3323.

NEI, M. 1977. F-statistics and analysis of gene diversity in subdivided populations. Ann. Hum. Genet., 41, 225-233.

NEI, M. 1978. Estimation of average heterozygosity and genetic distance from a small number of individuals. Genetics, 89, 583-590.

PECK, J. H., PECK, C. J. AND FARRAR, D. R. 1990. Comparative life history studies and the distribution of pteridophyte populations. Am. Fern J., 80, 126-142.

RANKER, T. A. 1987. Experimental systematics and population biology of the fern genera Hemionitis and Gymnopteris with reference to Bommeria. Ph.D. dissertation, University of Kansas, Lawrence, KS.

RANKER, T. A., HAUFLER, C. H., SOLTIS, P. S. AND SOLTIS, D. E. 1989. Genetic evidence for allopolyploidy in the neotropical fern Hemionitis pinnatifida (Adiantaceae) and the reconstruction of an ancestral genome. Syst. Bot., 14, 439-447.

SCHAAL, B. A. 1980. Measurement of gene flow in Lupinus texensis. Nature, 284, 450-451.

SCHEMSKE, D. W. AND LANDE, R. 1985. The evolution of selffertilization and inbreeding depression in plants. II. Empirical observations. Evolution, 39, 41-52.

SCHNELlER, J. J., HAUFLER, C. H. AND RANKER, T. A. 1990. Antheridiogen and natural gametophyte populations. Am. Fern $J ., 80,143-152$.

SCOTT, R. J. AND HICKOK, L. G. 1987. Genetic analysis of antheridiogen sensitivity in Ceratopteris richardii. Am. J. Bot., 74, 1872-1877.

SLATKIN, M. 1985. Rare alleles as indicators of gene flow. Evolution, 39, 53-65.

SLATKIN, M. 1987. Gene flow and the geographic structure of natural populations. Science, 236, 787-792.

SLATKIN, M. AND BARTON, N. H. 1989. A comparison of three indirect methods for estimating average levels of gene flow. Evolution, 43, 1349-1368.

SOLTIS, D. E. AND SOLTIS, P. S. 1986. Electrophoretic evidence for inbreeding in the fern Botrychium virginianum (Ophioglossaceae). Am. J. Bot., 73, 588-592.

SOLTIS, D. E. AND SOLTIS, P. S. 1987a. Polyploidy and breeding systems in homosporous pteridophyta: a reevaluation. Am. Nat., 130, 219-232.

SOLTIS, D. E. AND SOLTIS, P. S. $1987 \mathrm{~b}$. Breeding system of the fern Dryopteris expansa: Evidence for mixed-mating. Am. J. Bot., 74, 504-509.

SOLTIS, P. S. AND SOLTIS, D. E. 1987c. Population structure and estimates of gene flow in the homosporous fern Polystichum munitum. Evolution, 41, 620-629.

SOLTIS, P. S. AND SOLTIS, D. E. 1988 . Genetic variation and population structure in the fern Blechnum spicant (Blechnaceae) from western North America. Am. J. Bot., 75, 37-44. 
SOLTIS, P. S. AND SOLTIS, D. E. 1990. Evolution of inbreeding and outcrossing in ferns and fern-allies. Plant Species Biol., 5, $1-11$.

SOLTIS, P. S., SOLTIS, D. E. AND HOLSINGER, K. E. 1988. Estimates of intragametophytic selfing and interpopulational gene flow in homosporous ferns. Am. J. Bot., 75, 1765-1770.

SOlTIS, P. S., SOlTIS, D. E., AND WolF, P. G. 1990. Allozymic divergence in North American Polystichum (Dryopteridaceae). Syst. Bot., 15, 205-215.

STOLze, R. G. 1981. Ferns and fern allies of Guatemala. Part II. Polypodiaceae. Fieldiana, New Series, No 6

SWOFFORD, D. L. AND SELANDER, R. B. 1989. BIOSYS-1. A computer program for the analysis of allelic variation in population genetics and biochemical systematics. Release 1.7. Illinois Natural History Survey. Urbana, IL.

TRYON, R. AND TRYON, A. F. 1982. Ferns and Allied Plants, Springer-Verlag, New York.

WAPLES, R. S. 1987. A multispecies approach to the analysis of gene flow in marine shore fishes. Evolution, 41, 385-400.

WEIR, B. S. AND COCKERHAM, C. C. 1984 . Estimating $F$-statistics for analysis of population structure. Evolution, 38, 1358-1370.

WILKIE, D. 1963. Genetic analysis of variation in the bracken prothallus. J. Linn. Soc. Bot., 58, 333-336.

WOLF, P. G., HAUFLER, C. H. AND SHEFFIELD, E. 1988. Electro- phoretic variation and mating system of the clonal weed Pteridium aquilinum (L.) Kuhn (Bracken). Evolution, 42, $1350-1355$.

WOLF, P. G., SHEFFIELD, E. AND HAUFLER, C. H. 1991. Estimates of gene flow, genetic substructure, and population heterogeneity in bracken (Pteridium aquilinum). Biol. J. Linn. Soc., 42, 407-423.

WORKMAN, P. L. AND NISWANDER, J. D. 1970. Population studies on southwestern indian tribes. II. Local genetic differentiation in the Papago. Am.J. Hum. Genet., 22, 24-49.

WRIGHT, s. 1931. Evolution in Mendelian populations. Genetics, 16, 97-159.

WRIGHT, s. 1943. Isolation by distance. Genetics, 28, $114-138$.

WRIGHT, s. 1951. The genetical structure of populations. Ann. Eugenics, 15, 323-354.

WRIGHT, S. 1965. The interpretation of population structure by $F$-statistics with special regard to systems of mating. Evolution, 19, 395-420.

WRIGHT, s. 1969. Evolution and the Genetics of Populations. Vol. 2. The Theory of Gene Frequencies, University of Chicago Press, Chicago, IL.

WRIGHT, s. 1978. Evolution and the Genetics of Populations. Vol. 4. Variability Within and Among Natural Populations, University of Chicago Press, Chicago, IL. 